\title{
Coil Strength
}

National Cancer Institute

\section{Source}

National Cancer Institute. Coil Strength. NCI Thesaurus. Code C106510.

The maximum voltage allowable to pass through an electromagnetic coil. 